\title{
Quantitative promoter hypermethylation analysis of RASSF 1A in lung cancer: Comparison with methylation-specific PCR technique and clinical significance
}

\author{
SU MAN LEE ${ }^{1}$, WON KEE LEE ${ }^{2}$, DONG SUN KIM ${ }^{1}$ and JAE YONG PARK ${ }^{3}$ \\ Departments of ${ }^{1}$ Anatomy, ${ }^{2}$ Preventive Medicine, and ${ }^{3}$ Internal Medicine, School of Medicine, \\ Kyungpook National University, Daegu 702-422, Republic of Korea
}

Received May 31, 2011; Accepted September 27, 2011

DOI: $10.3892 / \mathrm{mmr} .2011 .608$

\begin{abstract}
Lung cancer is the major health problem and leading cause of cancer-related deaths worldwide owing to late diagnosis and poor prognosis. Aberrant promoter methylation is an important mechanism for silencing tumor-suppressor genes in cancer and a promising tool for the development of molecular biomarkers. Ras association domain family $1 \mathrm{~A}$ (RASSF1A), a pivotal gatekeeper of cell cycle progression, is highly methylated in a wide range of human sporadic tumors, including lung cancer. However, no significant prognostic implications have been observed in most studies qualitatively analyzed by methylation-specific PCR (MSP). We found that the RASSF1A promoter was aberrantly methylated in 44.7 and $37.4 \%$ of the tumors by pyrosequencing (PS) and MSP methods, respectively. RASSF1A methylation evaluated by the two methods was more frequent in ever-smokers and tumors with TP53 mutation than in never-smokers and tumors without TP53 mutation, respectively. Univariate and multivariate analyses revealed that strong methylation was an unfavorable prognostic factor with stage I (adjusted HR, 2.25; 95\% CI 1.034.90; $\mathrm{P}=0.003$ ) and squamous cell carcinoma patients (adjusted $\mathrm{HR}=2.25,95 \%$ CI 1.03-4.90, $\mathrm{P}=0.042$ ). Taken together, these results suggested that quantitative PS could gain wider applications in clinical samples as a promising method for early detection screening and prognosis compared with MSP.
\end{abstract}

Correspondence to: Dr Dong Sun Kim, Department of Anatomy, School of Medicine, Kyungpook National University, 2-101 Dongin-dong, Jung-gu, Daegu 702-422, Republic of Korea

E-mail: doskim@knu.ac.kr

Dr Jae Yong Park, Department of Internal Medicine, School of Medicine, Kyungpook National University, 2-101 Dongin-dong, Jung-gu, Daegu 702-422, Republic of Korea

E-mail: jaeyong@knu.ac.kr

Key words: methylation, lung cancer, RASSF1A, survival outcome, pyrosequencing, methylation-specific PCR

\section{Introduction}

Lung cancer, the leading cause of cancer-related mortality worldwide, is unique among common malignancies in that it does not have a proven screening or early detection strategy (1). Of note, lung cancer is a heterogeneous group of diseases made up of entities characterized by distinct clinical, pathological, morphologic and genetic features (2). However, the molecular basis of these variations in behavior and epidemiology is not yet well known.

Aberrant methylation of $\mathrm{CpG}$ islands within the gene promoter associated with transcriptional inactivation is as common as gene mutations are in human cancer (3). This change may also drive cells toward a certain oncogenic pathway, predisposing cells to the accumulation of genetic mutations (4). A wealth of evidence has indicated that multiple tumor-related and tumor suppressor genes (TSGs) are frequently methylated in lung cancer (5-7). In addition, tobacco smokers are predisposed to acquire multiple epigenetic alterations in key cellular regulatory genes within the respiratory tract (8). Accordingly, identification of aberrantly methylated genes may improve the clinical management of lung cancer by facilitating earlier disease diagnosis and providing more accurate prognostic information. There is now a wide range of methods to analyze the methylation status (9). Methylation-specific PCR (MSP) and pyrosequencing (PS) are highly rapid, sensitive and robust methods, thus amenable to broad usage $(10,11)$. The former information is considered only qualitative, while the latter offers quantitative analysis of multiple $\mathrm{CpG}$ sites.

Ras association domain family 1A (RASSF1A), a negative effector of RAS, functions as a tumor suppressor in cancer through several distinct pathways, including apoptosis, genomic and microtubule stability, and cell cycle regulation (12). RASSF1A methylation is frequently found in a variety of human cancers, including lung cancer $(13,14)$. To date, the prevalence of RASSF1A methylation is exhibited in $30-40 \%$ of non-small cell lung cancers (NSCLCs), which have mainly been determined by MSP analysis (12). However, only one study of methylation status by PS analysis has been performed in NSCLCs (15). Furthermore, there is no report to compare RASSF1A methylation status in NSCLCs by qualitative MSP and quantitative PS methods, and correlate 
their results with survival outcomes of patients with NSCLC. Herein, to determine which method may have greater clinical utility, we evaluated the methylation status of the RASSF1A gene promoter by means of MSP and PS in a large number of NSCLC tissue specimens, and then compared the results.

\section{Materials and methods}

Patients and tissue samples. Tumor and corresponding non-malignant lung tissue specimens were provided by the National Biobank of Korea, Kyungpook National University Hospital (KNUH; Daegu, Korea), which is supported by the Ministry of Health, Welfare and Family Affairs. All materials derived from the National Biobank were obtained under Institutional Review Board approved protocols. The clinicopathological characteristics of the patients are summarized in Table I. A total of 140 males and 66 females with a mean age of $62.5 \pm 8.6$ years were included in this study. There were 60 never-smokers and 146 ever-smokers (current- or formersmokers) with a mean pack-years of $27.5 \pm 24.6$. The histological types of NSCLSs were 84 cases of squamous cell carcinomas (SCCs) and 122 adenocarcinomas (ACs). Regarding the pathological stages, there were 130 cases at stage I and 76 cases at stage II-IV. All of the tumor and macroscopically normal lung tissue samples were obtained at the time of surgery, rapidly frozen in liquid nitrogen and stored at $-80^{\circ} \mathrm{C}$ until genomic DNA preparation. Only tumors with $>80 \%$ of the tumor components were sent for DNA extraction and methylation analysis. The macroscopically normal lung tissues were confirmed to be normal by H\&E staining. In addition, mutations of the TP53 (entire coding exons) and EGFR (exons 18-21) genes were detected by PCR-based direct sequencing.

Genomic DNA isolation and bisulfite treatment. Genomic DNA was extracted from primary tumors and corresponding non-malignant lung tissues using a QIAamp DNA Mini kit (Qiagen, Valencia, CA, USA) in accordance with the manufacturer's instructions. Extracted DNA samples were treated with sodium bisulfite (Sigma, St. Louis, MO, USA) and purified by using a Wizard DNA clean-up system (Promega Corporation, Madison, WI, USA), as described previously (16). CpGenome $^{\mathrm{TM}}$ Universal methylated and unmethylated DNA (Chemicon, Temecula, CA, USA) were treated the same way and were used as a positive control for the methylated and unmethylated genes in MSP and PS, respectively.

Pyrosequencing. Methylation of the RASSF1A gene promoter was quantitatively analyzed by PS method. Briefly, bisulfite-modified DNA was amplified using forward (5'-GTTAGGGTTCGGATGTGGGGATTT-3') and reverse primers (biotin-5'-TACCCTTCCTTCCCTCCTTC-3') through PCR, enabling the conversion of the PCR product to a singlestranded DNA template suitable for PS. All samples were heated to $95^{\circ} \mathrm{C}$ for $5 \mathrm{~min}$ and then amplified for 45 cycles at $95^{\circ} \mathrm{C}$ for $45 \mathrm{sec}, 58^{\circ} \mathrm{C}$ for $45 \mathrm{sec}$ and $72^{\circ} \mathrm{C}$ for $45 \mathrm{sec}$, followed by a final extension at $72^{\circ} \mathrm{C}$ for $5 \mathrm{~min}$. Confirmation of PCR product quality and freedom from contamination was established on $2 \%$ agarose gels with ethidium bromide staining. Following purification of the PCR product using Sepharose beads on PyroMark Vacuum Prep Workstation (Qiagen), PS was performed according to the manufacturer's specifications with sequencing primer (5'-AAAGTTGGTTTTTAGAAATA-3') using the PyroMark Q96MD System (Qiagen). A mean methylation index (MI) was calculated from the mean of the methylation percentage for all observed $\mathrm{CpG}$ sites. To set the controls for PS, we used CpGenome ${ }^{\mathrm{TM}}$ Universal methylated and unmethylated DNA that were consistently positive or negative with stable levels of methylation. We tested each DNA in triplicate and used their average in the statistical analyses.

Methylation-specific PCR. The methylation of the RASSF1A gene targeting the same region validated by PS was qualitatively performed on the bisulfite-treated DNA by using a MSP as previously described (17). All PCR amplifications were performed using reagents supplied in a GeneAmp DNA Amplification kit with AmpliTaq Gold as the polymerase (PE Applied Biosystems, Foster City, CA, USA) on PTC-100 (MJ Research, Watertown, MA, USA). Negative control samples without DNA were included for each set of PCR. PCR products were analyzed on $2 \%$ agarose gel, stained with ethidium bromide and visualized under ultraviolet (UV) light. The reproducibility of the results was confirmed by repeating the MSP analysis for each DNA sample. A portion of the PCR products was purified using PCR purification kit (Qiagen) and directly sequenced to confirm their methylation status.

Statistical analysis. The relationship between the methylation and the clinicopathological characteristics was analyzed using a Chi-square test or Fisher's exact test for categorical variables. A logistic regression analysis was conducted to estimate the relationship between methylation and the covariates of age, gender, exposure to tobacco smoke and histology. Overall survival (OS) was measured from the day of surgery until the date of death or to the date of the last follow-up. The survival estimates were calculated using the Kaplan-Meier method. The differences in OS across different groups were compared using the log-rank test. Hazard ratios (HRs) and 95\% confidence intervals (CIs) were estimated using multivariate Cox proportional hazards model.

\section{Results}

Methylation status of RASSF1A gene in NSCLCs. PS analysis was undertaken on 206 malignant and 40 non-malignant lung tissues resected from NSCLC patients. Accurate and reproducible estimates of methylated cytosine content were obtained in $100 \%$ of the tested samples and the representative programs are shown in Fig. 1A. Considering a maximal methylation index (MI) (4.69\%) in all non-malignant samples, we used an $\mathrm{MI} \geq 5$ as a cut-off point for methylation-positive classification. The RASSF1A promoter was methylated in 92 (44.7\%) of the 206 NSCLCs and 1 (2.5\%) of 40 non-malignant samples (Table I), suggesting that promoter methylation of the RASSF1A gene is not an intrinsic, developmentally programmed event, but a de novo, tumor-specific event. Furthermore, using a median MI (17.36\%) for 92 methylated samples as a cutoff point, the methylation-positive tumors were divided into two groups, weak-methylation $(5 \leq \mathrm{MI}<17)$ and strong-methylation (MI $\geq 17$ ). Methylation prevalence of the two groups was $28.8 \%$ (Table I). In addition, we also determined the methylation status 
Table I. Correlation between RASSF 1A methylation and clinicopathological features in the NSCLC patients.

\begin{tabular}{|c|c|c|c|c|c|c|c|c|}
\hline \multirow[t]{2}{*}{ Variables } & \multicolumn{6}{|c|}{ Pyrosequencing } & \multicolumn{2}{|c|}{$\begin{array}{c}\text { Methylation-specific } \\
\text { PCR }\end{array}$} \\
\hline & $\begin{array}{l}\text { Overall } \\
\mathrm{n}(\%)\end{array}$ & P-value & $\begin{array}{l}\text { Weak }^{\mathrm{a}} \\
\mathrm{n}(\%)\end{array}$ & P-value & $\begin{array}{l}\text { Strong }^{\mathrm{b}} \\
\mathrm{n}(\%)\end{array}$ & P-value & $\begin{array}{l}\text { Methylation } \\
\mathrm{n}(\%)\end{array}$ & P-value \\
\hline All subjects $(\mathrm{n}=206)$ & $92(44.7)$ & & $46(28.8)$ & & $46(28.8)$ & & $77(37.4)$ & \\
\hline $\begin{array}{l}\text { Age (years) } \\
\leq 63(n=103) \\
>63(n=103)\end{array}$ & $\begin{array}{l}38(36.9) \\
54(52.4)\end{array}$ & 0.025 & $\begin{array}{l}22(25.3) \\
24(32.9)\end{array}$ & 0.291 & $\begin{array}{l}16(19.8) \\
30(38.0)\end{array}$ & 0.011 & $\begin{array}{l}34(33.0) \\
43(41.7)\end{array}$ & 0.195 \\
\hline $\begin{array}{l}\text { Gender } \\
\text { Female }(n=66) \\
\text { Male }(n=140)\end{array}$ & $\begin{array}{l}24(36.4) \\
68(48.6)\end{array}$ & 0.100 & $\begin{array}{l}14(25.0) \\
32(30.8)\end{array}$ & 0.442 & $\begin{array}{l}10(19.2) \\
36(33.3)\end{array}$ & 0.065 & $\begin{array}{l}19(28.8) \\
58(41.4)\end{array}$ & 0.080 \\
\hline $\begin{array}{l}\text { Smoking status } \\
\text { Never }(n=60) \\
\text { Ever }(n=146)\end{array}$ & $\begin{array}{l}19(31.7) \\
73(50.0)\end{array}$ & 0.016 & $\begin{array}{l}10(19.6) \\
36(33.0)\end{array}$ & 0.081 & $\begin{array}{r}9(18.0) \\
37(33.6)\end{array}$ & 0.043 & $\begin{array}{l}16(26.7) \\
61(41.8)\end{array}$ & 0.042 \\
\hline $\begin{array}{l}\text { Histological type } \\
\text { SCC }(n=84) \\
\text { AC }(n=122)\end{array}$ & $\begin{array}{l}38(45.2) \\
54(44.3)\end{array}$ & 0.890 & $\begin{array}{l}19(29.2) \\
27(28.4)\end{array}$ & 0.912 & $\begin{array}{l}19(29.2) \\
27(28.4)\end{array}$ & 0.912 & $\begin{array}{l}32(38.1) \\
45(36.9)\end{array}$ & 0.860 \\
\hline $\begin{array}{l}\text { Pathological stage } \\
\text { Stage I }(n=130) \\
\text { Stage II-IIIA }(n=76)\end{array}$ & $\begin{array}{l}51(39.2) \\
41(53.9)\end{array}$ & 0.040 & $\begin{array}{l}27(25.5) \\
19(35.2)\end{array}$ & 0.199 & $\begin{array}{l}24(23.3) \\
22(38.6)\end{array}$ & 0.041 & $\begin{array}{l}44(33.8) \\
33(43.4)\end{array}$ & 0.171 \\
\hline $\begin{array}{l}\text { P53 } \text { mutation }^{\mathrm{c}} \\
\text { Absent }(\mathrm{n}=106) \\
\text { Present }(\mathrm{n}=66)\end{array}$ & $\begin{array}{l}33(31.1) \\
37(56.1)\end{array}$ & 0.001 & $\begin{array}{l}21(22.3) \\
16(35.6)\end{array}$ & 0.099 & $\begin{array}{l}12(14.1) \\
21(42.0)\end{array}$ & $<0.001$ & $\begin{array}{l}31(29.2) \\
31(47.0)\end{array}$ & 0.019 \\
\hline $\begin{array}{l}E G F R \text { mutation }{ }^{\mathrm{d}} \\
\text { Absent }(\mathrm{n}=137) \\
\text { Present }(\mathrm{n}=41)\end{array}$ & $\begin{array}{l}52(38.0) \\
23(56.1)\end{array}$ & 0.039 & $\begin{array}{r}30(26.1) \\
8(30.8)\end{array}$ & 0.627 & $\begin{array}{l}22(20.6) \\
15(45.5)\end{array}$ & 0.005 & $\begin{array}{l}48(35.0) \\
18(43.9)\end{array}$ & 0.300 \\
\hline
\end{tabular}

${ }^{a}$ Weak methylation, $5 \leq \mathrm{MI}<17$; ${ }^{\mathrm{b}}$ strong-methylation, $\mathrm{MI} \geq 17$. ${ }^{\mathrm{c}, \mathrm{d}}$ The mutations of $P 53$ and $E G F R$ genes were studied in 172 and 178 of the 206 NSCLCs. NSCLC, non-small cell lung cancer; MI, methylation index; SCC, squamous cell carcinoma; AC, adenocarcinoma.

$\mathbf{A}$

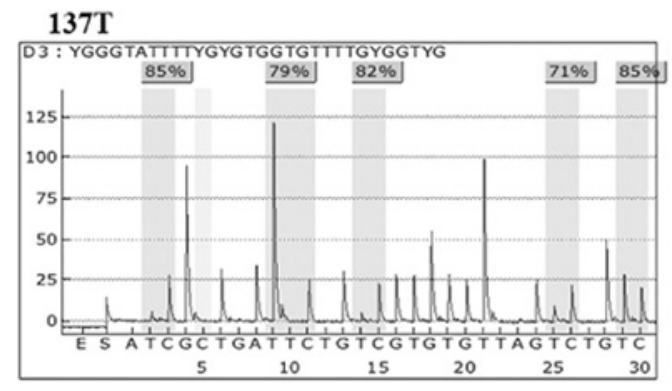

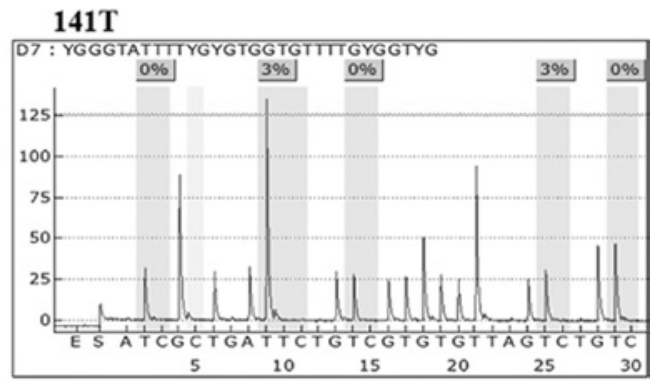

UD $\quad \begin{array}{lllllll}\text { MD } & 56 & 89 & 137 & 141 & 194 & 255\end{array}$

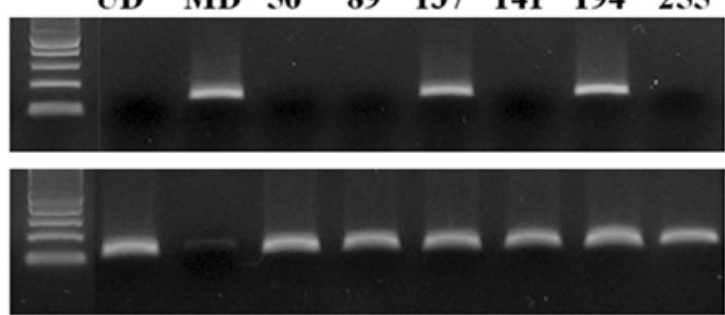

Methylated Allele

Unmethylated Allele

Figure 1. (A) Representative pyrograms and (B) methylation-specific PCR for the RASSF1A gene. (A) The letters on the axis represent the dispensation order; E, enzyme mix; S, substrate; A, G, C and T, nucleotides. Shaded bars encompassing T/C pairs, indicate five interrogated CpG's. The methylation of each CpG site was calculated as a percentage of $\mathrm{C}$ incorporation. (B) CpGenome ${ }^{\mathrm{TM}}$ universal methylated or unmethylated DNA was used as a positive control for the methylated or unmethylated products, respectively. 

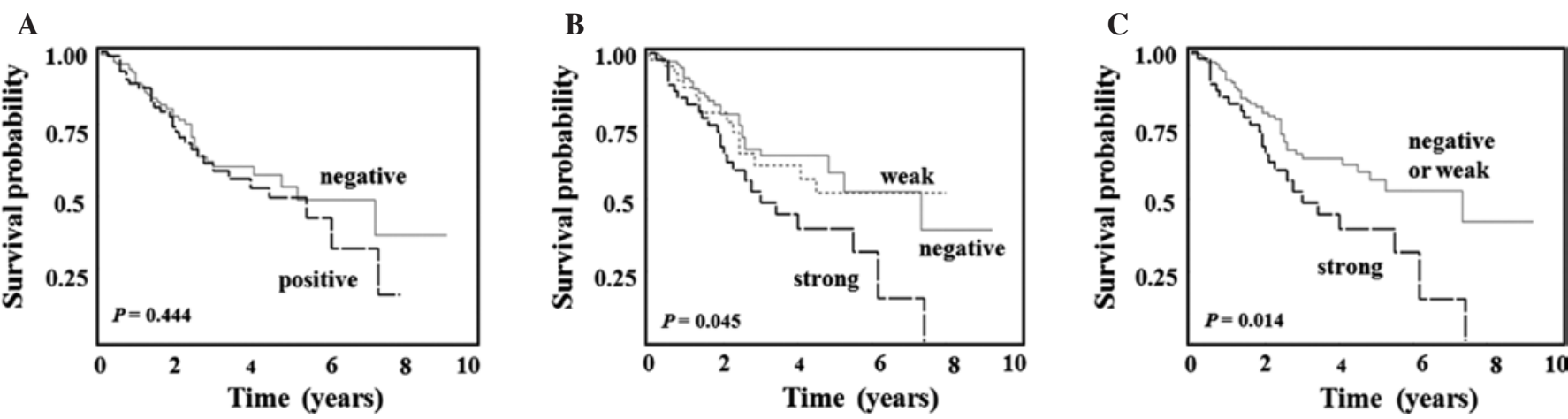

Figure 2. Overall survival curves of patients according to RASSF1A methylation status evaluated by (A) methylation-specific PCR and (B and C) by pyrosequencing. Negative, methylation index $(\mathrm{MI})<5$; weak, $5 \leq \mathrm{MI}<17$; and strong, $\mathrm{MI} \geq 17$. P-values from log-rank test.

Table II. Association of the methylation level of the RASSF1A gene with overall survival in NSCLC patients.

\begin{tabular}{|c|c|c|c|c|c|c|c|}
\hline \multirow{2}{*}{$\begin{array}{l}\text { Methylation } \\
\text { status }\end{array}$} & \multirow{2}{*}{$\begin{array}{c}\text { No. of cases } \\
(\%)^{\mathrm{a}}\end{array}$} & \multirow{2}{*}{$\begin{array}{l}\text { No. of deaths } \\
(\%)^{\mathrm{b}}\end{array}$} & \multirow{2}{*}{$\begin{array}{c}5 \text { years } \\
(\%)^{\mathrm{c}}\end{array}$} & \multicolumn{4}{|c|}{ Overall survival } \\
\hline & & & & $\operatorname{HR}(95 \% \mathrm{CI})^{\mathrm{d}}$ & P-value & $\begin{array}{l}\text { Adjusted HR } \\
(95 \% \mathrm{CI})^{\mathrm{d}}\end{array}$ & P-value \\
\hline Negative & $114(55.3)$ & $27(23.7)$ & 58.9 & 1 & & 1 & \\
\hline Weak & $46(22.3)$ & $15(32.6)$ & 56.7 & $1.16(0.62-2.19)$ & 0.639 & $1.02(0.54-1.93)$ & 0.945 \\
\hline $\begin{array}{l}\text { Strong } \\
\text { P-value }^{c}\end{array}$ & $46(22.3)$ & $25(54.4)$ & $\begin{array}{c}39.7 \\
0.045\end{array}$ & $1.93(1.12-3.33)$ & 0.018 & $1.27(0.72-2.25)$ & 0.413 \\
\hline Negative or weak & $160(77.6)$ & $42(26.3)$ & 56.5 & 1 & & 1 & \\
\hline $\begin{array}{l}\text { Strong } \\
\text { P-value }^{c}\end{array}$ & $46(22.3)$ & $25(54.4)$ & $\begin{array}{c}39.7 \\
0.014\end{array}$ & $1.84(1.12-3.01)$ & 0.016 & $1.26(0.75-2.13)$ & 0.389 \\
\hline
\end{tabular}

Negative methylation, MI $<5$; weak methylation, $5 \leq \mathrm{MI}<17$; strong methylation, $\mathrm{MI} \geq 17$. ${ }^{\mathrm{a} C o l u m n}$ percentage; ${ }^{b}$ row percentage. ${ }^{\mathrm{c}} 5$-year survival rate: proportion of survival derived from Kaplan-Meier estimator. P-value was calculated by the log-rank test. ${ }^{\mathrm{d} H a z a r d}$ ratio (HR), 95\% confidence interval (CI) and their corresponding P-values were calculated using Cox proportional hazard models and adjusted for age, gender, smoking status, tumor histology and stage. NSCLC, non-small cell lung cancer.

in 206 resected NSCLC samples using MSP. Representative examples of the MSP analysis are illustrated in Fig. 1B; methylation of the RASSF1A gene was found in 77 (37.4\%) of the 206 NSCLCs (Table I). In comparison between PS- and MSP-based methylation assessment, when the strong-methylation in PS assay was considered as methylation-positive, the concordance rate of methylation-positive samples was $97.8 \%$, but when the weak-methylation in PS assay was also included in the methylation-positive category, this led to a decrease in the concordance rate to $75 \%$ (data not shown).

Correlation of RASSF1A methylation status and clinicopathological characteristics. When methylation status was analyzed by PS assay, RASSF1A methylation was significantly associated with age, smoking status, pathological stage, EGFR and TP53 mutation. In addition, these associations were more pronounced in the strong-methylation group compared to the weak-methylation group (Table I). MSP data revealed that RASSF1A methylation was significantly associated only with smoking status and TP53 mutation (Table I).

Effect of RASSF1A methylation on survival outcome. Kaplan-Meier analysis revealed that RASSF1A methylation status determined by MSP did not significantly correlate with overall survival (OS) of the patients (Fig. 2A). However, according to the PS results the strong-methylation group was associated with a significantly worse OS compared to the negative-methylation group ( $\mathrm{P}=0.045$; Fig. $2 \mathrm{~B})$. In addition, the strong-methylation group exhibited a significantly worse OS compared to the combined negative- and weak-methylation group ( $\mathrm{P}=0.014$; Fig. $2 \mathrm{C})$. Unfortunately, a multivariate survival analysis using Cox proportional hazards model revealed that strong-methylation of the RASSF1A gene did not effect the survival outcome (adjusted HR, 1.26; 95\% CI 0.75-2.13; $\mathrm{P}=0.389$; Table II). Notably, when the patients were stratified according to pathological stage and histological types, RASSF1A strong-methylation was significantly associated with a worse survival in patients with stage I (adjusted HR, 2.25; 95\% CI 1.03-4.90; $\mathrm{P}=0.003$ ) and SCC patients (adjusted HR, 2.25; 95\% CI 1.03-4.90; P=0.042; Fig. 3 and Table III).

\section{Discussion}

In the present study, RASSF1A methylation was discovered in 44.7 and $37.4 \%$ of the tumors by PS and MSP assays, respectively, being consistent with the previous data that 

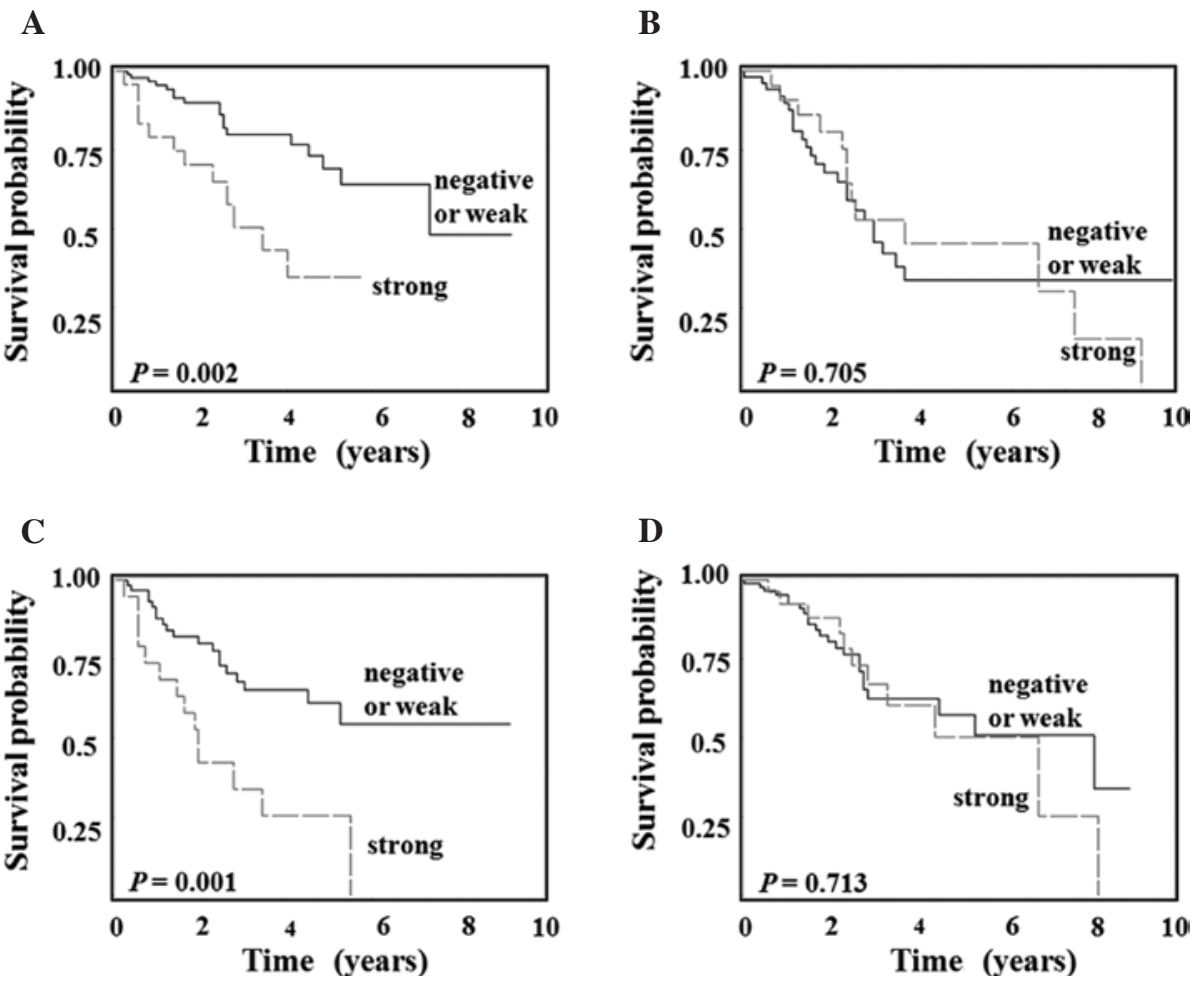

Figure 3. Kaplan-Meier survival curve of RASSF1A methylation levels according to pathological stage and tumor histology. P-values from log-rank test. (A) Stage I; (B) stage II-IIIA; (C) squamous cell carcinomas; (D) adenocarcinomas.

Table III. Multivariate analysis of overall survival with methylation level of RASSF 1A according to pathological stage and histologic type.

\begin{tabular}{|c|c|c|c|c|c|c|c|c|}
\hline \multirow[t]{2}{*}{ Variables } & \multirow{2}{*}{$\begin{array}{l}\text { Methylation } \\
\text { status }\end{array}$} & \multirow{2}{*}{$\begin{array}{l}\text { No. of cases } \\
(\%)^{\mathrm{a}}\end{array}$} & \multirow{2}{*}{$\begin{array}{l}\text { No. of deaths } \\
(\%)^{\mathrm{b}}\end{array}$} & \multirow{2}{*}{$\begin{array}{l}5 \text { years } \\
(\%)^{c}\end{array}$} & \multicolumn{4}{|c|}{ Overall survival } \\
\hline & & & & & $\mathrm{HR}(95 \% \mathrm{CI})^{\mathrm{d}}$ & P-value & $\begin{array}{l}\text { Adjusted HR } \\
(95 \% \mathrm{CI})^{\mathrm{d}}\end{array}$ & P-value \\
\hline \multirow[t]{2}{*}{ Stage I } & Negative or weak & $106(81.5)$ & $18(17.0)$ & 69.1 & 1 & & 1 & \\
\hline & $\begin{array}{l}\text { Strong } \\
\text { P-value }\end{array}$ & $24(18.5)$ & $12(50.0)$ & $\begin{array}{c}34.6 \\
0.002\end{array}$ & $1.84(1.12-3.01)$ & 0.016 & $3.10(1.48-6.51)$ & 0.003 \\
\hline \multirow[t]{2}{*}{ Stage II-IIIA } & Negative or weak & $54(71.1)$ & $24(44.4)$ & 33.8 & 1 & & 1 & \\
\hline & $\begin{array}{l}\text { Strong } \\
\text { P-value }\end{array}$ & $22(28.9)$ & $13(59.1)$ & $\begin{array}{l}45.3 \\
0.705\end{array}$ & $0.88(0.44-1.74)$ & 0.708 & $0.85(0.42-1.73)$ & 0.652 \\
\hline \multirow[t]{2}{*}{ SCC } & Negative or weak & $65(77.4)$ & $19(29.2)$ & 61.1 & 1 & & 1 & \\
\hline & $\begin{array}{l}\text { Strong } \\
\text { P-value }\end{array}$ & 19 (22.6) & $14(73.7)$ & $\begin{array}{c}25.3 \\
0.001\end{array}$ & $3.01(1.50-6.04)$ & 0.002 & $2.25(1.03-4.90)$ & 0.042 \\
\hline \multirow[t]{2}{*}{$\mathrm{AC}$} & Negative or weak & 95 (77.9) & $23(24.2)$ & 50.9 & 1 & & 1 & \\
\hline & $\begin{array}{l}\text { Strong } \\
\text { P-value }\end{array}$ & $27(22.1)$ & $11(40.7)$ & $\begin{array}{c}50.2 \\
0.713\end{array}$ & $1.14(0.56-2.35)$ & 0.715 & $0.67(0.31-1.47)$ & 0.317 \\
\hline
\end{tabular}

Negative methylation, $\mathrm{MI}<5$; weak methylation, $5 \leq \mathrm{MI}<17$; strong methylation, $\mathrm{MI} \geq 17$. ${ }^{\mathrm{a} C o l u m n}$ percentage; ${ }^{\mathrm{b}}$ row percentage. ${ }^{\mathrm{c}} 5$-year survival rate: proportion of survival derived from Kaplan-Meier estimator. P-value was calculated by log-rank test. ${ }^{\mathrm{d} H a z a r d}$ ratio (HR), $95 \%$ confidence interval (CI) and their corresponding P-values were calculated using Cox proportional hazard models and adjusted for age, gender, smoking status, tumor histology and stage. SCC, squamous cell carcinoma; AC, adenocarcinoma; MI, methylation index.

RASSF1A methylation is typically observed in $30-40 \%$ of NSCLCs (12-15). Moreover, regardless of the detection methods, RASSF1A methylation was more frequent in ever-smokers and TP53 mutation-positive tumors than in never-smokers and TP53 mutation-negative tumors, respectively.

Although MSP and PS data demonstrated no significant correlation between OS and methylation levels of the 
RASSF1A promoter in NSCLC patients, the strong-methylation of RASSFIA measured by PS was an unfavorable prognostic factor for stage I and SCC patients. Although a significant association between methylation status of the RASSF1A promoter and poor prognosis has been reported in lung cancer patients (17-19), our finding is the first report regarding the association of RASSF1A methylation levels with survival outcome. In this regard, it is reasonable to speculate that PS assessment may be more informative of prognosis and have greater potential clinical utility than MSP, being compatible with a recent finding (20). Although MSP and PS methods are sensitive enough to detect the low concentration of methylated alleles in target cells, the present study emphasizes the need to be more cautious in clinical interpretation of low-levels of methylation. Moreover, faint bands may be frequently observed on MSP analysis, potentially leading to interpretive difficulties. Therefore, considering the tissue heterogeneity that primary tumor tissues usually contain different fractions of target sequences (partial or complete methylation) and tumor cells, quantitative PS is gaining wider applications in clinical samples as a promising method for early detection screening and prognosis than MSP. However, additional studies are required to clarify the prognostic value of the methylation level of the RASSFIA gene in NSCLC.

Notably, considering the statistical power for the small number of methylated samples above background threshold, we used the median level of methylation observed by PS to classify tumors as weak vs. strong, and an association with survival was observed only in the 'strong tumors'. In actuality, when samples were repeated commencing with bisulfate medication, this cutoff would exclude or include some different tumors that, in turn, would probably affect the observed association to prognosis, indicating that this finding may simply be due to chance. However, we tested each tumor DNA in three replicates and used their average in the statistical analyses, ruling out this possibility. In addition, log-rank test of patients OS through a series of methylation levels seen by PS revealed that the lowest P-value was observed around the median level (data not shown). Similarly, Shaw et al have divided the methylated samples into a weak- and strong-methylated group using a median split, which is fortunately necessary to silence mRNA expression for the RASSF1A gene (21). Although there was an acute shortage of reasoning rationale for using median MI as a cutoff, our observation may offer new insight for the clinical management of methylation levels observed by PS.

\section{Acknowledgements}

This study was supported by the Korea Science and Engineering Foundation (KOSEF) grant funded by the Korean Government (MOST) (2010-0010000).

\section{References}

1. Jemal A, Siegel R, Ward E, Murray T, Xu J and Thun MJ: Cancer statistics 2007. CA Cancer J Clin 57: 43-66, 2007.
2. Minna JD, Roth JA and Gazdar AF: Focus on lung cancer. Cancer Cell 1: 49-52, 2002.

3. Baylin SB and Herman JG: DNA hypermethylation in tumorigenesis: epigenetics joins genetics. Trends Genet 16: 168-174, 2000.

4. Baylin SB and Ohm JE: Epigenetic gene silencing in cancer a mechanism for early oncogenic pathway addiction? Nat Rev Cancer 6: 107-116, 2006.

5. Belinsky SA: Gene-promoter hypermethylation as a biomarker in lung cancer. Nat Rev Cancer 4: 1-11, 2004.

6. Tsou JA, Hagen JA, Carpenter CL and Laird-Offringa IA: DNA hypermethylation analysis: a powerful new tool for lung cancer diagnosis. Oncogene 21: 5450-5461, 2002.

7. Yanagawa N, Tamura G, Oizumi H, Takahashi N, Shimazaki Y and Motoyama T: Promoter hypermethylation of tumor suppressor and tumor-related genes in non-small cell lung cancers. Cancer Sci 94: 589-592, 2003.

8. Alberg AJ, Brock MV and Samet JM: Epidemiology of lung cancer: looking to the future. J Clin Oncol 23: 3175-3185, 2005.

9. Shames DS, Minna JD and Gazdar AF: Methods for detecting DNA methylation in tumors: from bench to bedside. Cancer Lett 251: 187-198, 2007.

10. Herman JG, Graff JR, Myohanen S, Nelkin BD and Baylin SD: Methylation-specific PCR: a novel PCR assay for methylation status of CpG islands. Proc Natl Acad Sci USA 93: 9821-9826, 1996.

11. Colella S, Shen L, Baggerly KA, Issa JP and Krahe R: Sensitive and quantitative universal pyrosequencing methylation analysis. Biotechniques 35: 152-156, 2003.

12. Agathanggelou A, Cooper WN and Latif F: Role of the Ras-association domain family 1 tumor-suppressor gene in human cancers. Cancer Res 65: 3497-3508, 2005.

13. Hesson LB, Cooper WN and Latif F: The role of RASSF1A methylation in cancer. Dis Markers 23: 73-87, 2007.

14. Dammann R, Schagdarsurengin U, Seidel C, Strunnikova M, Rastetter M, Baier, K and Pfeifer GP: The tumor suppressor RASSF1A in human carcinogenesis: an update. Histol Histopathol 20: 645-663, 2005.

15. Vaissiere T, Hung RJ, Zaridze D, et al: Quantitative analysis of DNA methylation profiles in lung cancer identifies aberrant DNA methylation of specific genes and its association with gender and cancer risk factors. Cancer Res 69: 243-252, 2009.

16. Kim DS, Kim MJ, Lee JY, Kim YZ, Kim EJ and Park JY: Aberrant methylation of E-cadherin and $\mathrm{H}$-cadherin genes in nonsmall cell lung cancer and its relation to clinicopahological features. Cancer 110: 2785-2792, 2007.

17. Burbee DG, Forgacs E, Zochbauer-Muller S, et al: Epigenetic inactivation of RASSF1A in lung and breast cancers and malignant phenotype suppression. J Natl Cancer Inst 93: 691-699, 2001.

18. Tomizawa Y, Kohno T, Kondo H, et al: Clinicopathological significance of epigenetic inactivation of RASSF1A at 3 p21.3 in stage I lung adenocarcinoma. Clin Cancer Res 8: 2362-2368, 2002.

19. Kim DH, Kim JS, Ji YI, Shim YM, Kim H, Han H and Park J: Hypermethylation of promoter is associated with the age at starting smoking and a poor prognosis in primary non-small cell lung cancer. Cancer Res 63: 3743-3746, 2002.

20. Lee ES, Issa JP, Roberts DB, Williams MD, Weber RS, Kies MS and El-Naggar AK: Quantitative promoter hypermethylation analysis of cancer-related genes in salivary carcinomas: comparison with methylation-specific PCR technique and clinical significance. Clin Cancer Res 14: 2644-2672, 2008.

21. Shaw RJ, Hall GL, Lowe D, et al: CpG island methylation phenotype (CIMP) in oral cancer: association with a marked inflammatory response and less aggressive tumour biology. Oral Oncol 43: 878-886, 2007. 